\title{
Oil terrorism-militancy link: Mediating role of moral disengagement in emergency and crisis management
}

\author{
Oluwasoye Patrick Mafimisebi, PhD Student \\ Sara Thorne, $\mathrm{PhD}$
}

\begin{abstract}
The controversial issues of terrorism and militancy have generated contemporary interests and different interpretations have emerged on how to combat and manage these dangerous events. This study widens understanding of moral disengagement mechanism application in the perpetuation of inhumanities within the context of oil terrorist and militant behaviors. The research findings and model are explicit on how people form moral evaluations of agents who are forced to make morally relevant decisions over times in context of crisis situations. Quite crucially, understanding the context of terrorism and militancy provides policymakers, emergency and crisis managers better analysis and response to such events. The research fundamental purpose was to investigate the mediating role of moral disengagement on delinquency of oil terrorism and militancy; and considered implications for emergency and crisis management practices. The study found that situational-induced crises such as oil terrorism and militancy were sufficient to account for an individual's misdeeds and unethical or inhumane decisions made under frustration and agitation may be perceived as less indicative of one's fundamental character. Findings suggest that more repugnant delinquencies could have been committed in the name of justice than in the name of injustice, avenues for future research. In context, the result of the moral disengagement scale shows that morality of delinquency (oil terrorism and militancy) is accomplished by cognitively redefining the morality of such acts. The main finding is that people in resistance movements are rational actors making rational choices. The authors argue that theorists, policymakers, and practitioners must give meaningful attention
\end{abstract}

to understanding the multidimensional nature of emergency, crisis and disaster management for better strength of synthesis between theory and practice. The research is concluded by thorough examination of the implication and limitations for future research and practice.

Key words: moral disengagement, oil terrorism, militancy, emergency, crisis and disaster

\section{INTRODUCTION}

In this research, the construct of moral disengagement was applied in the context of emergency and crisis management of oil terrorism and militancy in Nigeria. However, these terms "emergency, crisis and disaster" continue to be problematic in concepts, methodologies, and applications in the face of dangerous events such as terrorism and militancy. The research findings and model are explicit on how people form moral evaluations of agents who are forced to make morally relevant decisions over times in context of crisis situations. We argue that theorists, policymakers, and practitioners must give meaningful attention to understanding the multifacet nature of emergency, crisis and disaster management for better strength of synthesis between theory and practice. A useful analogy is the traditional argument put forward by Quarantelli ${ }^{1}$ in the debate entitled "what is a disaster?" Where it was asserted that the main reason for clarification is because otherwise scholars who think they are communicating with one another are really talking of somewhat different phenomena. Crucially, this research did not advance such debate but reveal the relevance of understanding that emergency, crisis and disaster are practically different and 
depend on the context, location, and knowledge of first responders.

A number of theorists have acknowledged the difference between emergency, crisis and disaster management. ${ }^{1-7}$ Borodzicz ${ }^{2}$ provided some useful clarification of the terms-emergencies, crises and disasters. It has been acknowledged in past research that a risk could give rise to a crisis which in turn could become a disaster. In differentiating between the terms, the definitions presented by Borodzicz ${ }^{2}$ can provide valuable insights for their management: emergencies can be defined as situations requiring a rapid and highly structured response where the risks for critical decision makers can, to a relative degree, be well defined. Crises are also situations requiring a rapid response but the risks for critical decision makers are difficult to define owing to an ill-structure in the situation. However, a disaster can be defined as a cultural construction of reality and distinct from both emergency and crisis because it represents the product of the former. ${ }^{2}$ This definition implies that a disaster may typically involve dealing with a number of smaller ongoing crises and emergencies. The central argument offered here is that emergencies, crises and disasters management differ conceptually and practically thus requiring a multidisciplinary approach for effective sustainability.

In fact, to better understand emergency, crisis and disaster, and design effective proactive and pragmatic strategies, it is important that one has an understanding of what it means to different people in different parts of the world. More realistically, concepts and strategies are only relevant when they reflect the local interpretations because infusing global (or perhaps a segmental-like Western, Asia, Arab, or African) meaning to solve unstructured and unconventional crises (eg, oil terrorism and militancy) can be catastrophic in itself if local risk perceptions are exclusively neglected. Perhaps, this is the reason emergency and crisis management strategies and practices in recent years appear ineffective and unsustainable. The suggestion is to think globally but act locally when responding to cases of emergency and crisis management. We also note that disasters are the irreversible and typically overwhelming result of ill-handled emergency and crisis. ${ }^{2}$ Quite debatable, Dombrowsky ${ }^{3}$ advanced that "disasters do not cause effects. The effects are what we call a disaster." More clearly, evidence suggest that in managing disaster we may typically be involved in responding and dealing with a number of related partial emergencies and crises. This analogy is particularly useful in the context of oil terrorism and militancy incidents. The next section examines and reviews the relevant salient constructs to advance the theory and practice of emergency and crisis management.

\section{A REVIEW OF RELEVANT SALIENT CONCEPTS}

There are several salient concepts in this research that need to be defined and discussed in the context of the research background and focus. The growing security concerns over terrorism and militancy incidents across the globe have generated considerable interest among practitioners and academics. ${ }^{8-11}$ However, since the 9/11 terrorists attack, it appears that modern cases of terrorism and militancy are a fight not against terrorists and militants but a fight against ideology and fanaticism. ${ }^{12,13}$ This perspective to the phenomenon of terrorism has been adopted by some countries but this is not particularly the main approach for what terrorism is and how the threat should be reduced for most countries. However, the Nigerian perspective of terrorism is based on the legislative (Economic and Financial Crimes Commission [EFCC] Act 2004) framework which appears to categorize resistance movement/ insurgency or civil disobedience as terrorism. As the science and theory of terrorism settles on clear considerations around the counterterrorism response to the reduction of seemingly problematic unstructured crisis such as oil terrorism and militancy, increasing attentions and strategies have principally focus on consequences and reduction or containment strategies. However, as leaders (government authorities and agencies) and managers (organizations and relevant firms affected) grapple with the realities of developing response strategies tailored to what is perceived as global problem with local origin, the consequential implications are clear.

These response strategies are not particularly tailored toward the context of such dangerous events (eg, 
oil terrorism and militancy) and perhaps even neglect normative concerns and implications for sustainable emergency and crisis management practice. In reality, effective strategies toward terrorism-related and militancy-related crises should be tailored to specific vulnerability and geographic location and therefore the paucity of clear regional strategies becomes a leading constraint in decision-making process. In Nigeria, terrorism is broadly defined in section 15 of the EFCC (Establishment) Act 2004 as follows:

... any act which is a violation of the Criminal Code or the Penal Code and which may endanger the life, physical integrity or freedom of, or cause serious injury or death to any person, any number or group of persons or causes or may cause damage to public or private property, natural resources, environmental or cultural heritage and is calculated or intended to intimidate, put in fear, force, coerce or induce any government, body, institution, the general public or any segment thereof, to do or abstain from doing an act, or adopt or abandon a particular stand point or to act according to certain principles; or disrupt any publicservice, the delivery of any essential service to the public or to create a public emergency; or create general insurrection in a state; or any promotion, sponsorship of, contribution to, command, aid, incitement, encouragement, attempt, threat, conspiracy, organising, or procurement or any person, with the intent to commit any acts stated above...

The oil terrorism and militancy in the Niger Delta when viewed in the context of the legal framework of EFCC Act 2004 appears to constitute terrorism* and can be fruitless as every form of resistance or civil disobedience can be perceived as terrorism according

\footnotetext{
*This definition of terrorism as used in this research is controversial because it is not in line with local risk perception of the Niger Delta crisis and certainly not in line with how most western researchers have use the term. However, as argued in this research, definition is only relevant to serve a purpose.
}

to the EFCC Act. Nevertheless, there is no superiority of definition in terrorism and the idea that because the definition of the phenomenon (terrorism) (as used in this research) is not in line with how most western researchers use the concept calls for avoidance of its use in the Nigerian perspective can be misleading. This is because there is no consensus on the universal application of the phenomenon (terrorism) and as such its use should be subjected to local context even though agreement exists on the need for global collaboration. ${ }^{8,9,12-14}$

In practice, a number of Niger Delta people do not perceive oil terrorism and militancy as terrorism rather a struggle for self-determination against exploitation of their natural resources by the Nigerian state and environmental degradation by international oil companies. This is evidence from the support given to what many local people describe as a liberation struggle/resistance movement and movement toward sustainable local communities. ${ }^{15,16}$ This implies that when local risk perceptions of terrorism and militancy are entirely discounted, emergency and crisis management strategies devoted to end such terrorism and related crises cannot be sustainable. Therefore, relevant strategies and approaches of emergency and crisis management in dealing with oil terrorism and militancy must be locally relevant and grounded in local languages and cultures. Although oil terrorism and militancy have global implications and as such perceived as global problem that requires collaborative global strategies, it is clearly naïve to design global crisis management strategies for what perhaps is controversially and locally charged crises.

It is equally important to state that terrorism as a concept is widely disputed and debated in research and there are no generally acceptable definitions of the term. In the last decades, the scopes and definitions of terrorism have undergone extensive academic discussions. Terrorism implies intentionality, vulnerability, and psychological impact. ${ }^{10}$ Terrorism risk is seen as uncontrollable ${ }^{17}$ and may add to the level of fear experienced because risks that are perceived as "low control" are related to worrying. ${ }^{11}$ It is argued that terrorism creates more fear and anxiety than naturally occurring crisis with similar consequences. ${ }^{18,19}$ 
The risk perception of terrorism which is influenced by threat, uncertainty, and control ${ }^{17}$ may be grossly overestimated. It has been found that an act of terrorism differs ${ }^{20}$ and therefore its concepts can be argued to be relevant to the circumstances under which terrorismrelated crises exist.

In the context of oil terrorism and militancy in the Niger Delta, several other studies and media have further claimed that the Niger Delta people are forced to insurgency and violence because the Nigerian state uses military power to repress them and deny them of justice ${ }^{16,21-27}$ over environmental degradation and pollution. Similarly, Ken Saro-Wiwa (before his gruesome and extrajudicial killing), writer and environmental right activist stated that in this most sophisticated and unconventional war, in which no bones are broken, no blood spilled, and no one is maimed ... yet men, women, and children die, flora, fauna, and fish perish; the air and water are poisoned, and finally the land dries up. ${ }^{28}$ This argument resonate the position and controversial issue surrounding the Niger Delta crisis.

\section{MILITANCY AND OIL TERRORISM}

Militancy is defined as a violent and active behavior principally of the defense and support of a cause (mainly political) which often lead to the point of extremism. Therefore, a militant could be described as a person involved in hostile or a protest movement in the defense of a cause. This definition reflects some activities perpetrated by youths in the Niger Delta region of Nigeria on account of environmental and sustainability problems. In this perspective, three types of militants (intellectual militant, militant mobilizer, and violent militant) are identified in previous research. ${ }^{24}$ The focus here is on violent militants in the Niger Delta who often kidnap oil workers for ransom, attack oil pipelines, installations, and platforms with explosives, and the seizure of oil barges, oil wells, flow stations and support vessels, and other oil facilities including state assets to prevent the exploitation and/ or distribution of crude oil or its refined products.

Conversely, oil terrorism means the deliberate acts of blowing up oil pipelines, installations, and platforms with explosives, and seizure of oil barges, oil wells, flow stations, support vessels, and other oil facilities to prevent the exploitation and/or distribution of crude oil or its refined products. ${ }^{29}$ The Movement for the Emancipation of the Niger Delta (MEND) performed the first act of oil terrorism in Nigeria when they blew up Shell's Opobo pipeline in Delta State. ${ }^{30}$ Why interest in oil terrorism and militancy in the Delta? The Delta region has overestimated 40 billion barrels in oil reserves and places Nigeria as the biggest oil producer in Africa and eleventh in the world. Oil crisis in the Delta significantly affect both national and international communities in several forms. ${ }^{15,31}$ For example, fewer crises in the Niger Delta region of Nigeria lead to increase in Nigeria oil production output thereby balancing the global oil supply which consequently help stabilize price. However, the contrast would happen when there are increased crises within the Niger Delta region of Nigeria.

Oil terrorism is perpetuated by the militants within the Niger Delta region of Nigeria. The presumption has fuelled the believe that oil terrorism can be avoided by wholesale transformation of Niger Delta militants, a core reason for the presidential declaration of amnesty in the Delta on June 25, 2009 to curb militancy and encourage militants to abandoned violence. ${ }^{15}$ The amnesty proclamation meant that all persons who have directly or indirectly participated in the commission of offences associated with militants' activities in the Niger Delta were to surrender and hand over all equipment, weapons, arms, and ammunitions including execution of the renunciation of Militancy Forms specified in the schedule. ${ }^{32}$ Under the amnesty program, ex-militants are paid monthly allowance and undergo rehabilitation and skills acquisition training programs (home and abroad) melt to reintegrate them into society. However, the presumed solution of amnesty to the Niger Delta militants to curb oil terrorism and militancy is misleading and may be encouraging other disgruntled youths to further perpetuate violent behavior.

\section{MORAL DISENGAGEMENT: OIL TERRORISM AND MILITANCY ISSUE}

A number of studies have revealed that the decline of civic virtues, unethical behavior in different contexts of social life, ${ }^{33-35}$ and war, genocide, corruption, violent 
behavior, terrorism, ${ }^{36-41}$ and organization crises and disasters ${ }^{15}$ are perpetuated and disengaged through mechanisms of moral disengagement. These mechanisms (moral justification, attribution of blame, dehumanization, and diffusion of responsibility, distorting the consequences, euphemistic labeling, advantageous comparison, and displacement of responsibility) allow people to misbehave without feeling obliged to any kind of reparation and without carrying any need to change the moral standards they are ignoring. ${ }^{42(\mathrm{p} 504)}$ Therefore, oil terrorism and militancy may be mediated by the role of moral disengagement. Thus, this study explicitly draws a narrow focus on oil terrorists or militants' behavior rather than consequences which are a signature feature of moral cognition. We propose that oil terrorism and militancy link is related indirectly through the construct of moral disengagement. ${ }^{15,36,37}$ The theory of moral disengagement seeks to explain or analyze the means through which individuals rationalize their unethical or unjust actions. This is oftentimes missed in the study of terrorism and insurgency but imperative for building sustainable emergency and crisis management in the context of oil terrorists and militants' behaviors.

Moral disengagement can affect detrimental behavior both directly and indirectly. ${ }^{43}$ Social cognitive theory addresses the exercise of moral agency. ${ }^{44}$ The disengagement may centre on redefining harmful conduct (oil terrorism and militancy) as honorable by moral justification, exonerating social comparison, and sanitizing language. In another context, it may focus on agency of action (environmental degradation and self-determination) so that perpetrators (militants) can minimize their role in causing harm by diffusion and displacement of responsibility. Furthermore, it may involve minimizing or distorting the harm that flows from detrimental actions; and the disengagement may include dehumanizing and blaming the victims of the maltreatment. ${ }^{45}$ What is clear from research is that notion of moral disengagement may have influence on oil terrorists and militants' behavior. Indeed, in this explanatory framework, personal factors, such as moral thought and self-evaluative reactions, moral conduct, and environmental influences operate as interacting determinants of each other. ${ }^{43,46,47}$
Individuals may try to justify their militant behavior using the mechanisms of moral disengagement. For example, prototypical evidence might be "it is alright to destroy oil pipelines and national assets because of environmental degradation." Similarly, particularly as concerns the Niger Delta crisis, the act of vandals may be linked to construct of diffusion of responsibility and euphemistic labeling. More specifically, militant acts such as "people who treat militants as animals should be treated as such," "it is alright to intentionally attack international oil companies and Nigerian security agents because they collaborate to pollute the Delta," and "attacking international oil companies and oil platform is the expression of frustration and agitation in the Delta" become morally palatable. Interestingly, research indicates that moral actions are the product of the reciprocal interplay of cognitive, affective, and social influences. ${ }^{45}$

In conclusion, this research clarifies the mediating role of moral disengagement in the context of oil terrorism and militancy activities. Most essentially, the work explicitly seeks to contribute to our understanding of normative mechanisms that could affect "sustainable emergency and crisis management." The ultimate aims of the research are as follows: 1) critically explore how moral disengagement perpetuate oil terrorism and militancy incidents and consider implications for sustainable emergency and crisis management and 2) to encourage deeper reflection and evaluation of the possible implications of moral disengagement mechanisms on sustainable emergency and crisis management.

\section{METHOD}

\section{Participants}

A total of 753 ex-militants (89 percent male and 11 percent female) who were members of the MEND and the Niger Delta People's Volunteer Force (NDPVF) from Port Harcourt (Nigeria) served as participants. The participants were not considered as a control group because the principal aim of the research is not to experiment but measures attitudes among militants. Although the sample can be considered as experimental group because it contains mainly exmilitants, there are no alternative identical groups in 
which to compare the results. This is due to the several ethical implications involved in investigating moral disengagement in processes of crisis management. A classic example is the proposal to evaluate and measure moral disengagement of military personnel when combating terrorism. In control group, there are two identical experiments that are performed-treatment or tested factor (experimental group) in which the experiment is conducted and group (control) in which the tested factor is not applied. In this research, the ideal control group would have been local indigenes with the same characteristics of those in the experimental group (ex-militants). This situation likewise raises an ethical issue: how can we measure and evaluate moral disengagements of a group that are not inclined to terrorism and militancy. This can be subject of future research investigation. The participants were recruited through the assistance of two conflict resolution experts who help facilitate contacts with them. Following previous research, ${ }^{42,47,48}$ a survey instrument was adapted and developed. Although the participants were recruited through purposive sampling techniques (as to enable actors involved in the phenomena under investigation to be recruited), a detail letter covering the research aim was sent to the two conflict resolution experts for assessment and feedback. The survey was completed after three rounds between November 2013 and January 2014. The consents of the participants were sought and participants had the options to voluntarily withdraw from the study if they felt uncomfortable. The samples were part of a larger current $\mathrm{PhD}$ research investigating vulnerable people and vulnerable environment-moral disengagement in processes of organizational crisis.

\section{Measures}

Frequency of oil terrorism attack. The participants were asked to self-rate how frequently they attack a) oil pipelines and platforms, b) Nigerian state assets, c) international oil companies on a six-point scale (from 6 = every month, 5 = every 2 weeks, $4=$ every week, $3=$ every 3 days, $2=$ everyday, to $1=$ never). However, the participants' data have been protected through the research design because of the possible risks to them and the investigators. Personal data of the participants were completely eliminated and the interpretations of the findings were categorically anonymous to comply with ethical implications of conducting a sensitive research like this.

Moral disengagement. The study measured moral disengagement through the civil moral disengagement scale develops by Caprara et al. ${ }^{47}$ Ex-militants rated their degree of acceptance of moral exonerations presented in 32 items covering the eight different mechanisms through which moral self-sanctions can be disengaged from oil terrorist and militant conduct. The scale was considered as unidimensional $(\alpha=$ 0.89 ) similar to the original study, and a prototypical item is "It is alright to destroy oil pipelines and state assets because of environmental degradation in the Delta." The moral disengagement scale was initially developed as a 40-item scale by Bandura et al. ${ }^{37}$ and Caprara et al. ${ }^{47}$ However, the scale was modified to ensure compatibility with the research context and background, and therefore reduced to 32 items four for each mechanism of moral disengagement which the participants responds to on a five-point Likert scale (from $1=$ strongly disagree, to $5=$ strongly agree).

Demographics. The participants indicated their age and gender. The age of the participants range between 19 and 42 years $(\mathrm{M}=21.50, \mathrm{SD}=8.3)$. The surveys showed that nine percent had finished primary education, 51 percent finished secondary education, 25 percent finished tertiary education, and 15 percent had finished university education.

Self-recounted delinquency. The degree of ex-militants involvement was measured through a 10 -item self-report list. Participants were asked to indicate how many times they had involved in oil terrorismrelated activities during the past 10 years. Items were grouped into two main dimensions. Oil terrorism (five items, $\alpha=0.87$, scores range from 0 to 17): for example, "bombing a petrol flow station" and "blowing up oil pipelines, installations, and platforms with explosives." Militancy conduct (five items, $\alpha=0.82$, scores range from 0 to 20): for example, "have been involved in seizure of oil barges, oil wells, flow stations, support 
vessels" and "threatened the Nigerian government over oil facilities."

\section{Ethical issues and implications}

The selected participants in this research have been granted the Nigerian Presidential Amnesty. The amnesty proclamation was made on the June 25, 2009 specified in the Nigeria First Amnesty Proclamation Section 175 of 1999 Constitution. ${ }^{32}$ It would have make no practical sense theorizing on the concepts of oil terrorism and militancy without actual investigation of the people involved in such acts. Oftentimes, studies in the area of terrorism and militancy have advanced without real involvement of the people affected in such moral delinquency. In contrast, this study gives valuable knowledge about how perpetrators rationalize their actions. In this respect, this study adds valuable knowledge to a research field that should talk more with perpetrators and use first hand data. However, in achieving the research aim, there are several numbers of ethical issues and implications that must be clarify here.

First, it was clear that oil terrorism and militancy as discussed in this research cannot be explained in abstraction without actual investigation of those who are directly involved in such acts. The ethical issues when asking perpetrators (ex-militants) to report criminal behaviors require clarification. These participants (ex-militants) understood the purpose of the study because they have been briefed and consent to participate in the research. The participants perceived their local communities to be unsustainable because of environmental disasters (pollution, oil spillage, land contamination, gas flaring, extreme weather, and climate change) and therefore are more interested in sustainable communities. There was general agreement that responding with violence as means of protest over environmental disasters and oil pollution in the Niger Delta (Nigeria) is not a sustainable method of expressing frustration and agitation. Therefore, in this regards, this research fail to engage and spread the political message of the activists (ex-militants).

Second, it may appear questionable why ex-militants will benefit from telling the truth because the participants could benefit from reporting that they have committed criminal activities to spread their political message. Likewise, the participants could fail to report their criminal activities because this could involve the risk of being caught and punished for breaking the law. However, it is established that these participants were known offenders because they were part of the Nigerian government presidential amnesty program. Furthermore, there is no political message to spread by these participants because they were already part of government rehabitation and integration program. In this regards, this research fall shorts of spreading political message of activists but instead provides valuable insights on how first line responders (emergency and crisis managers) can deal with the dangerous events of oil terrorism and militancy in Nigeria.

\section{RESULTS}

As revealed by the participants of the current study, the findings show that they did not frequently engage in oil terrorism and militancy conduct. However, a significant number indicated that they would not mind when left with no alternative options (46.3 percent). In context, 25.8 percent of the participants declared to rarely engage in oil terrorism and militancy, 11.3 percent noted to have been frequently involved in oil pipelines vandalism, and blowing up oil pipelines and platforms with explosives, whereas 62.9 percent of the participants declared to have often engaged in oil terrorism and militancy conduct at some point. Although the number of female participants were low (11 percent) compared to the male participants, there is no statistical significance in terms of gender (Table 1). However, male participants were reported to have been involved in oil terrorism and militancy in the Delta.

In general, in terms of misbehavior (oil terrorism and militancy), at least 93.4 percent of the participants reported to have been involved in militancy conduct (46.7 percent has a score of more than 8) and 6.6 percent in oil terrorism-related offence (4.8 percent has a score of more than 12). This reveals that terrorists (ex-militants) have a vast set of tools at their disposal to conduct oil terrorism-related and militancyrelated violence. Like in previous research, ${ }^{49,50}$ male 


\begin{tabular}{|c|c|c|c|c|c|}
\hline Measures & $\mathbf{M}$ & SD & M male & M female & $\mathbf{F}$ \\
\hline \multicolumn{6}{|c|}{ Frequency of oil terrorism attack } \\
\hline Oil pipelines and platforms & 7.81 & 2.20 & 7.74 & 3.82 & 0.78 \\
\hline Nigerian state assets & 6.92 & 2.12 & 6.11 & 2.46 & 0.83 \\
\hline International oil companies & 5.36 & 2.54 & 5.47 & 3.04 & 0.50 \\
\hline \multicolumn{6}{|l|}{ Misbehavior } \\
\hline Oil terrorism & 4.38 & 2.07 & 5.67 & 2.39 & $49.82^{*}$ \\
\hline Militancy conduct & 5.72 & 1.89 & 5.22 & 2.97 & $35.92^{*}$ \\
\hline Moral disengagement & 4.67 & 1.31 & 4.87 & 3.31 & $45.08^{*}$ \\
\hline \multicolumn{6}{|c|}{$\begin{array}{l}\text { Note: Frequency of oil terrorism attack extended from } 1 \text { to } 6 \text {. Moral disengagement factors extended from } 1 \text { to } 8 \text {. Oil terrorism } \\
\text { extended from } 0 \text { to } 17 \text {. Militancy conduct extended from } 0 \text { to } 20 \text {. } \\
{ }^{p} p<0.001 \text {. }\end{array}$} \\
\hline
\end{tabular}

participants have more moral disengagement attributes than females. Furthermore, the findings indicate that moral disengagement has a mediating role in oil terrorism and militancy conduct (76.2 percent has a score of more than 9). This confirms the proposition that oil terrorism and militancy link is related indirectly through the construct of moral disengagement. This offers a sufficient explanation of understanding the contexts in which oil terrorism and militancy are established.

The result of the moral disengagement scale shows that morality of delinquency (oil terrorism and militancy) is accomplished by cognitively redefining the morality of such acts. The main message is that people in resistance movements are rational actors making rational choices. The possible implication in emergency and crisis management is that labeling an act as terrorism when it is perceived otherwise can lead to crisis intensification and exacerbate the message of the perpetrators. The definitions of what constitute terrorism are often disputable as reflected in situation where school violence ${ }^{7}$ and political group violence expressed by terrorist actions ${ }^{14}$ are considered as an act of terrorism. This confirm previous research position conducted in Australia ${ }^{51}$ that communication campaigns about terrorism-related crises have to be framed with caution to avoid negative reactions toward vulnerable people (or minorities).
In context, moral justification such as "it is alright to attack international oil companies and Nigerian government because they collaborate to pollute the Delta" becomes morally acceptable (89.7 percent). In another perspective, the present study found that 92.3 percent of the participants indicate that "attacking international oil companies and oil platforms, oil wells, and seizure of oil barge is the expression of frustration and agitation in the Delta." Research suggests that language shapes thought patterns on which actions are based. ${ }^{45}$ Our results further confirm Diener ${ }^{52}$ positions that people behave much more cruelly when assaultive actions are given a sanitized label than when they are called aggression. What this implies is that pure reliance on repressive policies to deal with oil terrorism and militancy can be counterproductive.

Although it is yet unknown what types of government actions (ie, nonmilitarization counterterrorism and militarization counterterrorism) are more effective in dealing with oil terrorism and militancy, the research findings suggest that sticks approach in defeating oil terrorism and militancy are unsustainable when contextualized over times. For example, in its brutal campaign against terrorism and militancy, would Nigerian's government be better off concentrating on arresting, torturing and killing terrorists (militants), or should it invest more resources into improving healthcare, 
education, roads, electricity, and essential public services for those who reject terrorist (militant) violence? The research findings suggest that what Nigerian government has done over the years to deal with oil terrorismrelated and militancy-related crises are mostly sticks approach which appears unsustainable and may have been responsible for crisis intensification. In another perspective, the perceived current carrot approach of amnesty program to militants (who represent a small proportion of the Niger Delta population of more than 35 million) has gained limited success.

In another insightful analysis, Bandura ${ }^{45}$ revealed that by exploiting the contrast principle reprehensible acts can be made righteous. The present findings reveal that "militants cannot be blamed if they engage in oil terrorism because multinational oil companies degrade the environment and deliberately destroy people's source of livelihood through oil exploration and exploitation activities in the Delta" (87.3 percent). This suggests that what was once morally condemnable becomes a source of self-valuation. ${ }^{45}$ Finally, overall majority of the participant reveal that "people cannot be held accountable for violence committed because they are push to the wall" (79.6 percent). This is displacement of responsibility as Bandura ${ }^{46}$ noted they view their actions as stemming from the dictates of authorities rather than being personally responsible for them. This makes it complicated to entirely rely on militarization approach in dealing with oil terrorism and militancy. As argued, the cognitive dimensions such as moral justification, euphemistic labeling, and advantageous comparison which influence an individual's response to oil terrorism and militancy require radical approaches to effectively manage. Furthermore, the recent dramatic swing in oil prices might impacts the subject matter of this research. For example, reduction in global oil prices reduces Nigerian government revenue. Petroleum exports revenue accounts for more than 90 percent of total exports revenue in Nigeria. Therefore, we expect that government approaches and strategies to oil terrorism and militancy in the Niger Delta region of Nigeria would change significantly. In this context, sustainable approach such as education, employment generation, reducing environmental risks, and host communities participation in oil production could be the game changers in resolving the crisis. Likewise, it is possible that there would be increased militarization approach in protecting critical infrastructure in the oil and gas industry. This would be likely because Nigerian government depends largely on petroleum exports revenue for governance.

\section{DISCUSSION}

The overall aim of this article was to analyze the mediating role of moral disengagement in the context of oil terrorist and militant conduct. The present research found that oil terrorism and militancy link is related indirectly through the construct of moral disengagement. For example, vandalism of oil pipeline is mostly blamed on unemployment, environmental pollution caused by multinational oil companies, and unsustainable means of livelihood. Therefore, the moral evaluation of such acts should be the focus of redirecting emergency and crisis management strategies when dealing with oil terrorism and militancy conduct. The results further show considerable evidence to argue that the mechanisms of moral disengagement have a mediating role in oil terrorism and militancy. In this perspective, our research findings established that more people are likely to engage in vandalism of oil pipeline and other delinquencies when possibilities to validate such actions exist. The mechanisms of moral disengagement permit different types of conduct (such as blowing up of oil pipelines, seizure of oil barge, bombing of oil platform, and kidnapping) to be perpetuated by militants with the same moral standards. This modifies people's risk perception and creates a need for sensemaking and socially supportive communication and engagement of stakeholders. Misperception of oil terrorism and militancy may cause cruel behaviors become morally palatable for delinquents, and make militarization approach becomes unsustainable.

Like in previous research, ${ }^{46,53,54}$ through moral justification of violent means, militants perceive themselves as fighting ruthless oppressors (international oil companies and Nigerian state), protecting their cherished values (environment and sources of livelihood), and saving humanity (Niger Delta people) from 
suppression and environmental degradation. Thus, it is critical to contextualize that it became necessary to destroy the town to save it. In other words, moral justifications sanctify the violent means. ${ }^{45}$ Indeed, as hypothesized, moral disengagement perpetuates oil terrorist and militant behavior. Findings indicated that militants were more likely to use the mechanisms of moral disengagement to justify their actions. What possible implications could this have on crisis management in the Delta? Should multinational oil companies and Nigerian state accept full responsibility for such acts because of environmental degradation? Besides, people will behave in ways they normally repudiate if a legitimate authority accepts responsibility for the effects of their conduct. ${ }^{52,55}$ Thus, it is clear that selfexemption from gross inhumanities through displacement of responsibility is revealed most gruesomely ${ }^{45}$ in oil terrorists and militants conduct.

Ex-militants rather believed extremism in defense of environmental right is no vice. ${ }^{56}$ This dictum represents an adamant belief that oil terrorism and militancy cannot be considered reprehensible considering that government officials are insensitive to the people plights; a view that 89.6 percent of the participants shared. In specific context, such belief represents distortion of consequences and further suggests that mechanisms of moral disengagement perpetuate and mediate militants conduct. Thus, as confirmation of existing research, ${ }^{45}$ moral disengagement mediate oil terrorist and militant conduct. In summary, it appears that more repugnant delinquencies have been committed in the name of justice than in the name of injustice. Perhaps, future research could investigate the role of moral disengagement in the process of seeking justice.

\section{CONCLUSION}

The research findings and model are explicit on how people form moral evaluations of agents who are forced to make morally relevant decisions over times. The study found that situational-induced crises such as oil terrorism and militancy were sufficient to account for an individual's misdeeds and unethical or inhumane decisions made under frustration and agitation may be perceived as less indicative of one's fundamental character. In contrast, the results suggest that emergency and crisis managers (ie, Nigerian government and agencies) are more likely to portray and treat such unethical or amoral behaviors as someone's (militant's) immoral character. Findings confirmed that moral disengagement influences oil terrorist and militant behavior. This enables people in resistance movements considered themselves as rational actors making rational choices. In critical context, this implies that in emergency and crisis management, considerable efforts should be on addressing the moral imbalance that exists between perpetrators and crisis responders. For example, establishing risk culture education programs for local communities and occasional (but regular) risk and crisis management forum that bring local communities, multinational oil companies, and government agencies together are most beneficial.

This exploratory research has revealed the mediating role of moral disengagement in the context of oil terrorist and militant conduct, and the impact these mechanisms might have on sustainable crisis management. However, given the relatively small samples used in the study and the limitations to a particular region (Nigeria, Africa), the research findings are not used to make definitive claims about oil terrorists' and militants' behavior globally. A more delicate limitation is implications of investigating moral disengagement without having a control group. This can impact the research findings because it would be difficult to conclude that the study measures attitudes among militants or something (attitudes) that are common in the Niger Delta area. Nonetheless, it should be acknowledged that the study used experimental group (ex-militants) as sample and therefore we can argue that the study measures attitudes among militants. It is essential that in future research, the issues surrounding control group are considered when reporting the findings. In an insightful perspective, we acknowledge that the current dramatic swing in oil prices may impact the subject matter contained in this research. For example, it is anticipated that Nigerian government response to oil terrorism and militancy will change to a more sustainable approach.

Despite such limitations, the study critically explores the mediating role of moral disengagement and how its mechanisms penetrate oil terrorist and 
militant behavior. It may be more relevant to work on the moral self-regulation of oil terrorist and militant as a way of disinhibiting their perceived inhumanities. As evidence from the study, morality is rooted in a self-reactive selfhood $^{45}$ and thus instituting lines of accountability could curtail moral disengagement. Furthermore, results suggest that more repugnant delinquencies could have been committed in the name of justice than in the name of injustice, avenues for future research. Additionally, the findings indicate that discussing how oil terrorism and militancy could practically affect people, environment and sustainable crisis management is crucial toward disinhibiting militants from such delinquency. In summary, moral disengagers (militants and oil terrorists) need to understand how their activities affect the world around them and how they could be morally engaged to seek sustainable crisis management approach. Hence, relevant authorities in Nigeria would need to engage them and discuss risk perception of environmental issues within the Delta.

Oluwasoye Patrick Mafimisebi, PhD Student, Department of Strategy, Enterprise \& Innovation, Portsmouth Business School, University of Portsmouth, Portsmouth, UK.

Sara Thorne, PhD, Senior Lecturer and Course Leader, Department of Strategy, Enterprise \& Innovation, Portsmouth Business School, University of Portsmouth, Portsmouth, UK.

\section{REFERENCES}

1. Quarantelli E: What is a disaster? Int J Mass Emerg Disasters. 1995; 13(3): 221-229.

2. Borodzicz EP: Risk, Crisis and Security Management. Chichester: John Wiley \& Sons Ltd, 2005.

3. Dombrowsky WR: Again and again: Is a disaster what we call 'disaster'?. Some conceptual notes on conceptualising the object of disaster sociology. Int J Mass Emerg Disasters. 1995; 13(3): 241-254. 4. Heinzen B: Crisis Management and Scenarios: The Search for an Approach Methodology. the Netherlands: Ministry of Home Affairs, 1996.

5. Lagadec P: Learning processes for crisis management in complex organisations. J Contingencies Crisis Manag. 1997; 5(1): 24-31.

6. Slovic P: Terrorism as hazard: A new species of trouble. Risk Anal. 2002; 22(3): 425-426.

7. Veil S, Mitchell K: Terror Management Theory: Promoting tolerance in campus safety campaigns. Int J Strateg Commun. 2010; 4: 207-224.

8. Becker SM: Risk communication and radiological/nuclear terrorism: A strategic view. Health Phys. 2011; 101(5): 551-558.

9. Fischhoff B: Communicating about the risks of terrorism (or anything else). Am Psychol. 2011; 66(6): 520-531.

10. Goldstein BD: Advances in risk assessment and communication. Annu Rev Public Health. 2005; 26(1): 141-163.
11. Lee JEC, Lemyre L, Krewski D: A multi-method, multi-hazard approach to explore the uniqueness of terrorism risk perceptions and worry. J Appl Soc Psychol. 2010; 40(1): 241-272.

12. Kearon T, Mythen G, Walklate S: Making sense of emergency advice: Public perceptions of the terrorist risk. Secur J. 2007; 20(2): 77-95.

13. Lockett JS, Domke D, Coe K, et al.: Going public, crisis after crisis: The Bush administration and the press from September 11 to Saddam. Rhetor Public Aff. 2007; 10(2): 195-220.

14. Gofin R: Preparedness and response to terrorism-A framework for public health action. Eur J Public Health. 2005; 15(1): 100-104.

15. Mafimisebi OP: Moral Disengagement in Processes of Organisational Crisis [MSc risk dissertation]. Portsmouth, UK: University of Portsmouth, 2013.

16. Mafimisebi OP, Nkwunonwo UO: The impacts of gas flaring and climate risks: An appraisal of Nigerian Petroleum Industry. Int $J$ Sci Eng Res. 2014; 5(4): 1071-1078.

17. Sheppard B: Mitigating terror and avoidance behaviour through the risk perception matrix to augment resilience. $J$ Homeland Secur Emerg Manag. 2011; 8(1): 1-21.

18. King NB: The ethics of biodefense. Bioethics. 2005; 19(4): 432446.

19. Schmid AP: The literature on terrorism. In Schmid AP (ed.): The Routledge Handbook of Terrorism. New York: Routledge Taylor \& Francis Group, 2011: 457-474.

20. Heilbrun K, Wolbransky M, Shah S, et al.: Risk communication of terrorist acts, natural disasters, and criminal violence: Comparing the processes of understanding and responding. Behav Sci Law. 2010; 28(6): 717-729.

21. Dafinone D: The Niger Delta crisis: Genesis, exodus and solution. The Vanduarg Daily. November 16, 2007: 25.

22. Ekpu R: The dilemma of Niger Delta. Newswatch. August 13, 2007: 10-30.

23. Ibaba SI: Understanding the Niger Delta Crisis. Port Harcourt: Amethyst and Colleagues Publishers, 2005.

24. Inokoba P, Imbua DI: Vexation and militancy in the Niger Delta: The way forward. J Hum Ecol. 2010; 29(2): 101-120.

25. Mbah G: The restive youths of the Niger. Insider. February 11, 2008: 17 .

26. Mafimisebi OP, Nkwunonwo UO: Environmental risk: Exploring organisational resilience and robustness. Int J Sci Eng Res. 2015; 6(1): 1103-1115.

27. Okonta I, Oronto D: Where Vultures Feast: Forty Years of Shell in the Niger Delta. Ibadan: Kraft Books Limited, 2001.

28. Bassey C, Oshita O: Conflict Resolution, Identity Crisis and Development in Africa. Lagos: Malthouse Press Ltd, 2007.

29. Alawode AJ, Ogunleye IO: Maintenance, security, and environmental implications of pipeline damage and ruptures in the Niger Delta Region. Pac J Sci Technol. 2011; 12(1): 565-573.

30. Ibinabo J: Port Harcourt Gunmen. The News. June 4, 2007: 3.

31. Nkwunonwo UO, Mafimisebi OP: Responding to the challenges of global climate change in Nigeria through GIS mapping of carbon IV oxide gas emission. Int J Sci Eng Res. 2013; 4(12): 765-774.

32. Nigeria First Amnesty Proclamation Pursuant to Section 175 of the Constitution of the Federal republic of Nigeria, being text of President Yar'Adua's Amnesty Proclamation, June 25, 2009. Available at http://news.bbc.co.uk/1/hi/world/africa/8118314.stm. Accessed August 5, 2015.

33. Detert JR, Trevino IK, Sweitzer VL: Moral disengagement in ethical decision making: A study of antecedents and outcomes. $J$ Appl Psychol. 2008; 93: 374-391. 
34. Moore C: Moral disengagement in processes of organisational corruption. J Bus Ethics. 2008; 80: 129-139.

35. Smith CA: President Bush's enthymeme of evil. The amalgamation of 9/11, Iraq and moral values. Am Behav Sci. 2005; 49(1): 32-47. 36. Bandura A: Moral disengagement in the preparation of inhumanities. Pers Soc Psychol Rev. 1999; 3: 193-209.

37. Bandura A, Barbaranelli C, Caprara B, et al.: Mechanisms of moral disengagement in the exercise of moral agency. J Pers Soc Physchol. 1996; 71: 364-374.

38. Fiske S: Social Beings: A Core Motives Approach to Social Psychology. New Jersey: John Wiley \& Sons, 2004.

39. Ntayi JM, Eyaa S, Ngoma M: Moral disengagement and the social construction of procurement officers' deviant behaviours. $J$ Manag Policy Pract. 2010; 11(4): 95-110.

40. Moore CJR, Detert JR, Trevino IK, et al.: Why employees do bad things: Moral disengagement and unethical organisational behaviour. Pers Psychol. 2012; 65: 1-48.

41. Paciello M, Fida R, Tramontano C, et al.: Stability and change of moral disengagement and its impact on aggression and violence in late adolescene. Child Dev. 2008; 79: 1288-1309.

42. Caprara GV, Fida R, Vecchione M, et al.: Assessing civil moral disengagement: Dimensionality and construct validity. Pers Individ Dif. 2009; 47: 504-509.

43. Bandura A, Caprara GV, Zsolnai L: Corporate transgressions through moral disengagement. J Human Values. 2000; 6: 57-64.

44. Bandura A: Social Foundations of Thought and Action: A Social Cognitive Theory. Englewood Cliffs, NJ: Prentice Hall, 1986.

45. Bandura A: Selective moral disengagement in the exercise of moral agency. J Moral Educ. 2002; 31: 101-119.

46. Bandura A: Social Cognitive Theory of moral thought and action. In Kurtines WM, Gewirtz JL (eds.): Handbook of Moral
Behaviour and Development: Theory, Research and Applications. Hillsdale, NJ: Erlbaum, 1991: 71-129.

47. Caprara GV, Barbaranelli C, Iafrate C, et al.: La misuradeldisimpegno morale nel context delletransgressionidell'ag rioquotidiano [Measuring moral disengagement in the context of transgression of daily living]. GiornaleItaliano di Psicologia. 2006; 33: 83-106.

48. Carlton SJ, Jacobson SK: Climate change and coastal environmental risk perceptions in Florida. J Environ Manage. 2013; 130: 32-39.

49. Cermak I, Blatny M: Personality indicators of aggression and moral disengagement. Stud Psychol. 1995; 37: 199-201.

50. Passini S: The delinquency-drug relationship: The influence of social reputation and moral disengagement. Addict Behav. 2012; 37: 577-579.

51. Stevens G, Agho K, Taylor M, et al.: Terrorism in Australia: Factors associated with perceived threat and incident-critical behaviours. BMC Public Health. 2009; 9(91): 1-9.

52. Diener E: Deindividuation: Causes and consequences. Soc Behav Pers. 1977; 5: 143-156.

53. Bandura A, Caprara B, Barbaranelli C, et al.: Sociocognitive self-regulative mechanisms governing transgressive behaviour. $J$ Pers Soc Psychol. 2001; 80: 125-135.

54. Beu D, Bucley M: This is war: How the politically astute achieve crimes of obedience through the use of moral disengagement. Leadersh Q. 2004; 15: 551-568.

55. Milgram S: Obedience to Authority: An Experimental View. New York: Harper \& Row, 1974.

56. Cesarz E, Morrison JS, Cooke J: Alienation and Militancy in Nigeria's Niger Delta. Washington, DC: Centre for Strategic and International Studies, 2003: CSIS Africa Notes, 16. 